\title{
RESTITUTION OF AGRICULTURAL LAND IN SERBIA - COMPARATIVE LEGAL ASPECTS
}

\author{
Ljiljana Rajnovićl, Snežana Cico ${ }^{2}$, Zoran Brljak ${ }^{3}$ \\ *Corresponding authorE-mail: rajnoviclj@gmail.com
}

A R T I C L E I N F O
Review Article
Received: 30 June 2020
Accepted: 28 September2020
doi:10.5937/ekoPolj2004353R
UDC
006.024:[341.384:631.4(497.11)

Keywords:

restitution, compensation, titular of restitution, principles of the constitution, discrimination, comparative legal practice, return of agricultural land

JEL: $Q 14, Q 15, Q 10, Q 18, K 11$

\section{A B S T R A C T}

The idea of returning the confiscated property to the previous owners in the Republic of Serbia arose as a process that included all the countries of Eastern Europe and other countries of the former communist system in which mostly state property existed. Restitution is part of the transition process, which implies comprehensive changes in the state, including privatization of the state sector and market operations on the principles of private property, but also as a need to correct the injustice done to former owners of confiscated property. According to Serbian legislation, restitution is obligatory, but in practice it is very difficult and slow to realize, even though this process realizes one of the basic human rights of citizens described in the UN Universal Declaration of Human Rights - the right to free enjoyment of private property. In this paper, the authors analyze the possibilities of returning agricultural land, legal regulations and implemented solutions in practice, on the example of a unit of local selfgovernment, on whose territory there is a state land fund that can be the subject of return.

(C) 2020 EA. All rights reserved.

\section{Introduction}

Restitution implies the return of property or rights that have in the past been unjustifiably taken away without adequate compensation from a certain person, group of citizens or an entire class, or ethnic group in countries where certain, significantly different social circumstances previously existed.

The terms "reprivatization" and "denationalization" are used in the same sense. In the legislation and practice of comparative law, the term denationalization, in a broader sense,

1 Ljiljana Rajnović Ph.D., Institute of Agricultural Economics, Belgrade, Volgina 15, Phone: + 38163273 237, E - mail: rajnoviclj@gmail.com, ORCID ID (https://orcid.org/00000002-8209-9088).

2 Snežana Cico Ph.D., Severtrans ad Sombor, Filipa Kljajića bb, Phone: + 381644402057 , E-mail: snezanacico@gmail.com, ORCID ID (https://orcid.org/0000-0003-3356-6767) .

3 Zoran Baljak, PhD Student of Education University of Novi Sad, Phone: +381 63320001 E-mail: zoran.brljak@educons.edu.rs, ORCID ID (https://orcid.org/0000-0001-6076-6102) 
also means the compensation of things and rights that have been taken away from private law subjects and transferred to the property of any other subjects (states, municipalities, agrarian stakeholders, etc.), by implementing any coercive measures of public authority (confiscation, nationalization, expropriation, etc.) in the process of taking away of private property.

In economic terms, denationalization also means privatization, sale of state or socially-owned property to private legal or natural persons. It is a significant process, of modern economic and social development, every country, which is increasingly based on private property, decentralization, deregulation and weakening of the regulatory and managerial role of the state. Denationalization is related to the processes of economic growth and progress, which is based on technological development, globalization and market competition, with the aim of renewing liberal values in economic and social life, and especially to the disintegration of socialist creations and the creation of open market economies. It is commonly believed that the advantages of private ownership are in greater initiative and motivation of private owners for more efficient management and operations as well as in greater mobility of goods, capital, labor, workforce and knowledge. Private ownership extends not only to all commercial sectors but also to areas of service of general interest, which have traditionally been in the sphere of state ownership and management.

In this paper, the authors deal with restitution as a process of returning property taken away to private ownership (primarily in natural form or in the form of compensation expressed in cash) which was taken away on the basis of earlier regulations from the communist period, confiscation and sequestration, agrarian reform and colonization, nationalization and expropriation or even without a legal basis, without fair compensation or in some other similar way (Gower, Kozminski, 1997). In the legal sense, restitution means the establishment of the previous situation in relation to the person from whom it was confiscated, in the way it was before the act of confiscation and refers primarily to the return of confiscated property, ie. in natural form (Jugović, 2009).

The return of property taken away is an issue that is simultaneously included in the process of transition of any post-communist country and, one of the unavoidable issues related to the European integration of a country that is interested in becoming a member of the European Union. But Protocol No. 1. in addition to the European Convention for the Protection of Human Rights and Fundamental Rights, does not create for the signatory states any general obligations or restrictions regarding the restitution of property (right to restitution, scope of return and conditions) taken away from former owners before ratifying the Convention. This issue is left to the states to decide (Judgment of the European Court of Human Rights).

Restitution is a complex issue from the not-so-distant past of the communist period, from a time that included:

- transformation,

- collectivization and nationalization of human consciousness and

- $\quad$ private property. 
This idea, regardless of the fact that it was based on the then legally valid normative framework and no matter how much it was realized through official authorities, had an aggressive approach conducted by a state that acted with the strength of its ius empire, degradation of human freedoms and property rights. Therefore, restitution is, in every country where it is implemented, a large state project based on the law. In addition, the real will of the current government is necessary, which not only returns the property to the former owners, but also definitely introduces a new philosophy of private property whose protection, until restitution is carried out, will still be only declarative (Projuris, 2020), on paper only.

Such a point of departure for re-privatization or restitution of property rights was not very promising and carried with it serious legal and political complications. It has also to be remembered, however, that there were several reasons for restitution of property (Surdykowska, 1996):

- ideology and, ,historical justice,, where the new capitalist society based on the principles of private ownership should start, by making good the cardinal sins against private property committed by the communist regimes,

- $\quad$ socialy, which suggested that the building of a new middle class should start by re -building teh old one, or a least a part of it,

- idea that the easiest and the mostnatural way of privatizing and assuring the most effective use of assets was to return the existing property to the original owners,

- a requirement of Europian Union, to comply with the principles of respecting property rights generally accepted in the western world.

\section{The aim of the work and the methodology used}

Information and data used for reserch in this paper, which refer to the process of restitution, which included all Eastern countries and part of the countries of Central Europe and other countries of the former communist system in which there was predominantly state property, including the return of agricultural land in the Republic of Serbia, were obtained during a detailed interview with fifty holders of restitution who claimed agricultural land in Vojvodina, on the analysis of legal regulations in Serbia and abroad, on numerous practical examples when returning the land and especially on the List published on the Agency's website.

During the research of the chosen topic, the following methods were used to collect and evaluate relevant information:

- Case studies as a descriptive method, showing that the observed cases can be taken as a typical case, showing that it is possible to return confiscated land of satisfactory quality, which can be concluded based on the existing quantity and quality of state-owned land. Within the presented cases, the authors started from concrete indicators from available public documents on the existence of a sufficient amount of quality state land, pointing out the importance of fair distribution and the consequences of not applying good solutions. 
- The comparative method enabled the authors to come to generalizations or new conclusions by comparing the same or similar phenomena or by establishing similarities and differences between them.

- The synthesis method was finally used to summarize the conclusions at the global level as well as at the level of Serbia, developed countries with recommendations for efficient and effective return of agricultural land and its role in creating sources of financing for new owners.

From the analysis of all collected data, it was noticed that there are possibilities for a fairer distribution of land in Serbia, which would benefit both parties in the restitution procedure, the state and the restitution creditor.

Additional data related to foreign markets are the result of many years of research by authors, relevant foreign scientific and professional literature, foreign institutions that play a role in postupcima vraćanja oduzete imovine, analysis of practical examples and publicly available information via the Internet.

The main goal of this paper is to show on the one hand, the possibility of returning agricultural land and on the other hand, law enforcement in practice. The research was conducted on the Serbian market in the period from 2012. to 2020.

The economic and the legal justification for the implementation of restitution is based on the process of including Serbia in the currents in Europe, harmonization of legal and economic frameworks with EU member states, correction of injustice done decades ago and creation of a new / old middle economic class.

The success of the restitution can undoubtedly be assumed based on the reputation and the economic strength of the state, the socially responsible behavior of the state including respect for human rights.

\section{Results of work with discussion}

\section{The subject of restitution and the position of the titular in the procedure of returning the taken away property}

The subject of restitution are things and rights that in the observed period were taken away by public authorities on the basis of the then regulations, decisions of courts and other authorities, but also without any legal basis taken away from the previous authorities. The Law on Restitution of Confiscated Property and Compensation of the Republic of Serbia distinguishes between:

- natural and

- financial restitution.

Which solution will be applied in a specific case depends on the legal solution, which may include the return of confiscated real estate and movables - natural restitution, or reduced exclusively to financial compensation, then we are talking about financial 
restitution (Samardžić, 2012). In the case of financial restitution, the state gives compensation to the holder of restitution instead of confiscated property in the form of government bonds of the Republic of Serbia and in money, in accordance with this law.

The holder of the right to restitution of property may claim the taken away property right in the legally prescribed procedure, only when the conditions prescribed by the state under which this "legitimate expectation" can be realized, occur, because the property does not exist until a claim can be established over it. (Decision of the Constitutional Court of Serbia No. I-Uz.119 / 2008 of 20.04.2011).

This follows from the provisions of the Constitution of the Republic of Serbia, which does not explicitly determine the right to return taken away property, nor the obligation of the legislator to regulate restitution, and such a right is not guaranteed by the European Convention for the Protection of Human Rights and Fundamental Freedoms. The Convention guarantees the holder the right to unhindered enjoyment of property, i.e. restriction of property rights and other property rights on any basis without compensation, which includes the prohibition of confiscation. However, since the Convention cannot be applied retroactively, it therefore does not establish the obligation of the state to eliminate violations of property rights that occurred before its entry into force. The Convention defines property, according to which property includes not only the right of ownership of immovable and movable property and investments in it, but also a claim based on which there is a legitimate expectation that the effective enjoyment of a property right can be acquired. That legitimate expectation is in fact an expectation from the restitution process.

The expectation that previously existing property rights will be recognized, which have not been able to be used effectively for a long time, does not constitute property within the meaning of the provisions of the said Convention. In order to exercise the right under the mentioned provisions of the Convention, it is necessary to have "at least a legitimate expectation" that a certain property right can be realized, and a legitimate expectation exists only when the contracting state prescribes the conditions under which that expectation will be realized. However, the signatory states to the Convention are not limited in prescribing the conditions under which they will return the property, which was transferred to them before they ratified the Convention (European Convention for the Protection of Human Rights and Fundamental Freedoms, 1950). The Republic of Serbia has prescribed by law the conditions under which it will return property to the right holders in the restitution procedure. This means, for example, if a request for restitution of property is submitted in accordance with the law, and it is necessary under the same law, as a prescribed condition, to rehabilitate the previous owner, the condition for restitution of property or compensation is acquired only when the rehabilitation decision becomes final.

In the practice of the Republic of Serbia, the question has been raised whether it is possible to speak of a violation of the prohibition of discrimination when persons who are in significantly different situations and exercise the right to return property and 
compensation under different laws. In order to resolve that issue, an initiative was launched at the Constitutional Court of Serbia.

The Constitutional Court has ruled that the Constitution of Serbia allows the possibility of pre-existing social or state property created by the original method of acquiring property - an act of the state (law, by-law or individual act) may, by an act of the state, in case of restitution, change the form of ownership by law, i.e. that it may be returned to private ownership, under the conditions prescribed by the law governing restitution. From this it can be concluded that there is a constitutional authority that the law governing restitution may regulate the conditions, manner and procedure of returning confiscated property and compensation, whereby it must be borne in mind that the property was confiscated on the basis of the constitution and regulations, were in force at the time the property was confiscated. This means that there was a legal basis for such confiscation of property, so in that sense it is logical in the current law that regulates the possibility to return confiscated property in natural form, or to provide compensation for confiscated property, as which is determined by the provisions of the existing law that regulates the return of confiscated property and compensation. The initiative for constitutional review in this sense was initiated due to the fact that, in the opinion of the initiator, persons entitled to return property under this law are placed in an unequal position in relation to other categories of persons exercising the right to return property under other regulations (Decision of the Constitutional Court of Serbia No. IUz-429/2011 of 18 April 2013).

In assessing the violation of the principle of non-discrimination, the understanding of the European Court of Human Rights may be taken into account, on the basis of which the right to the enjoyment of rights and freedoms provided by the same Convention is violated when States parties treat in similar situations, without stating objective and reasonable justifications (European Convention for the Protection of Human Rights and Fundamental Freedoms, 1950).

However, based on the opinion of the European Court of Human Rights, the principle of non-discrimination is also violated in the case when states do not treat people who are in significantly different situations differently without objective and reasonable justification. Based on the above, it can be concluded that persons exercising the right to return property under other regulations are in significantly different situations regulated by these regulations, such as, for example, in the case of return of agricultural land, compared to persons exercising the right to return property or compensation under the law governing the return of confiscated property and compensation, and based on the above, the Constitutional Court considers that these categories of persons are in an unequal position, because, on the contrary, equal treatment in different situations would mean substantial inequality in exercising rights, in the process of restitution of property and compensation (Decision of the Constitutional Court of Serbia No. IUz-429/2011 of 18 April 2013). 
Based on the above, it can be concluded that the holder of natural restitution and the holder of monetary compensation are not in the same position, but at the same time an explanation is given for the stated difference. In this regard, there is an objective and reasonable justification for the stated difference in the position of these two categories of former owners, which is based on the purpose or status of a certain real estate.

The position of the Constitutional Court of Serbia is based on the logic that the Constitution of Serbia allows the possibility that the previously taken away property can, again by an act of the state, in this case by law, change the form of that property, i.e. that it may be returned to private ownership, under the conditions prescribed by law. As stated above, this means that there is a constitutional authority that the law governing the return of taken away property regulates the conditions, manner and procedure of returning taken away property and compensation for taken away property, bearing in mind that the property in question was confiscated on the basis of previously valid constitutions and regulations, which means that there was a legal basis for such confiscation of property, whereby it is a matter of the legislator's determination to limit this right in the sense that it does not include the right to return fruits and compensation for loss of profit (Decision of the Constitutional Court of Serbia No. IUz-462/2011 of 11 April 2013).

The explanation for the above is based on the fact that the Constitution does not recognize the principle of equality as a general, abstract concept that applies to all legal entities in every legal situation, but guarantees equality within the same category of legal entities, i.e. the same type of rights. Based on the above, it can be concluded that the holders of the right to restitution are not in the same position:

- the former owner to whom the property is returned in natural form and

- the former owner who will receive compensation for the taken away property under the conditions and in the manner provided by this law.

But, in the opinion of the Constitutional Court, there is an objective and reasonable justification for the mentioned difference in the position of these two categories of former owners. It is a fact that certain real estate for objective reasons, arising from the purpose or status of real estate, in cases specified in the law governing the return of confiscated property and compensation can not be returned, and in these cases the former owner is entitled to compensation for confiscated property (Decision of the Constitutional Court of Serbia No. IUz-462/2011, April of 11 th, 2013$)$.

\section{Restitution in Serbia and post-communist countries}

It is indisputable that the violation of property rights was committed after the end of the Second World War, on the territory of the former Yugoslavia as well as in other countries of the communist regime, mainly the countries of Eastern Europe, on the basis of legal regulations of the then authorities or individual acts. Some of those states, later entered the process of transition, which meant a change in the state system, and decided on the path of European integration or are already members of the EU. Therefore, it was necessary to 
eliminate the injustice of violating the property rights of the previous owners, committed during the rule of the communist system. Some countries have already carried out the restitution procedure with more or less success, in a shorter or longer period, which depends not only on the adopted regulations but also on the real political and social will, which is reflected in the consistent implementation of constitutional principles and principles of the constitution and laws. Some countries, such as Serbia, are still conducting the restitution procedure, and the most problems are in the procedures whose subject is the return of agricultural land. According to agrarian analysts, there is enough state land to complete the process of restitution of agricultural land, but the restitution of agricultural land does not go in favor of the state (The Fate of Confiscated Property, Gulan, 2015). The best solutions cannot lead to results in practice if they are not implemented consistently, i.e. if not everyone is equal before the law and the constitution. This brings us back to the rule of law, which is a precondition for all changes and realization of individual rights of restitution holders.

The restitution procedure, in its essence and legal sense, implies a return to the situation from more than six decades ago. This procedure is in itself controversial and brings with it many problems and conditions prescribed by states, such as:

- obtaining extensive documentation that needs to be attached to the request for restitution of property,

- it is often necessary to rehabilitate the former owner of the confiscated property, which is, as stated, a condition for the return of property,

- and in Serbia it is envisaged that the current law on property restitution and compensation does not apply in Kosovo and Metohija.

During the implementation of restitution in other Eastern European countries, two main models were created:

- restitution in rem (restitution in natural form, i.e. the return of the same thing in its natural form) Legally speaking, natural restitution is the only proper and just form of restitution because it does not burden citizens with additional fees and the state has no additional financial costs. Also, it is not discriminatory and has been implemented in most countries in transition. Natural restitution is also a recommendation of the European Union and

- direct, mostly financial compensation through monetary compensation.

In addition to the above, a large number of states allow the combination of these two forms of return of confiscated property. In the countries of the European Union, there is no prescribed mandatory model of restitution, but different solutions are applied in different member states, such as the exchange of property in Slovenia. Therefore, most post-communist countries in Europe decided to combine these two models (Sutela, 1998), which was accepted by the Republic of Serbia by adopting the current law. Most countries initiated restitution proceedings in the 1990s. Among the first were Slovenia, the Czech Republic, Slovakia and Hungary. Then Bulgaria (1992), Germany, for East Germany (1994), Romania, Croatia and Poland (1996), Macedonia (1998), Montenegro (2002), Albania (2004), and the Republic of Serbia significantly later, in 2012 (IPF,2020). 
The extent of restitution titular compensation varies from state to state. The amount of compensation certainly depends on the political will of the state, but it is also conditioned by the economy of one state. In this regard, the countries in the process of transition, in order not to pay compensation in cash, decided to issue bonds maturing in a certain period of time, after the completion of the procedure of determining the rights of the restitution holder upon the submitted request. In Serbia, unlike most countries, this procedure takes an unreasonably long time. Many requests submitted to the competent institution with the beginning of the application of the law have not been resolved yet. Germany has set the compensation period for its eastern part at five years, and Macedonia at thirty, but both countries have provided for the payment of compensation in debt securities, with a country with stronger economic power, such as Germany, can pay off its obligations in a shorter period of time (HERETICUS, 2020).

In some countries, there is dissatisfaction of restitution holders because they believe that not everyone is in the same position, that some receive property of higher value and some less, proceedings are conducted for too long and there are numerous disputes before the International Court of Human Rights. Although Restitution removes the moral injustice done decades ago, it may not be ideal, but it is very important that it be fair and effective. It is also fair that the issue of restitution does not drag on for years, as it has in Serbia or for decades, as is the case in some countries. For example, in Romania, there are many dissatisfied holders who have initiated court proceedings due to inconsistent application of the current law. (Ceppei, 2020) or Poland, which decided to limit the compensation to $20 \%$ of the value of the property. On the other hand, there are countries in Central Europe that have carried out the restitution process faster and more efficiently, such as the Czech Republic, which has returned everything in natural form and where companies have already been built on confiscated land, the owners have received appropriate value of share capital in those companies. In Slovakia, restitution also had the priority of repossession of property in natural form, while Hungary resolved the issue in two years during the 1990s, opting for limited compensation. In Slovenia, restitution has been completed, unlike in Croatia, which has problems with the return of large farms. There are still unfinished proceedings in Macedonia (WJRO, 2020) and in Bulgaria there is dissatisfaction due to compensation in bonds. Montenegro is still delaying the process of returning taken away property. (IPF, 2020).

\section{Restitution of agricultural land in Serbia with the example of one local self-government unit}

The Law on the Return of Confiscated Property and Compensation stipulates of Serbia, that agricultural and forest land and forests, which were taken away by the application of previous regulations, are returned to the holders of restitution. If the taken away agricultural land was the subject of consolidation or land consolidation carried out after the confiscation, the former owner has the right to return the land obtained from the consolidation estate for that land (Law on Return of Confiscated Property and Compensation). 
The bylaw establishes the obligation of the Agency for Restitution (hereinafter: the Agency) to, on the basis of its data on claims from the submitted requests of restitution right holders, inform the Agricultural Land Administration (hereinafter: the Administration) about the areas of agricultural land claimed, in cadastral municipalities in which the consolidation procedure was carried out. Based on that, the Administration is obliged to determine state-owned cadastral parcels in an area that will be sufficient to complete the procedure of property restitution, and which may be subject to restitution in terms of the Law and this Regulation (Regulation on criteria for determining the area of agricultural and forest land in the process of returning taken away property).

The stated data, the List of determined cadastral parcels in state ownership that can be the subject of return in the procedure of return of confiscated property (hereinafter: the List) must be accurate, publicly published on the website of the Administration and the Restitution Agency. The Agency is obliged to update them daily, so that all interested parties have information about the plots that are intended to be returned in the restitution procedure, which have already been returned during the procedure and which are left for return.

At the same time, there can be no cadastral parcels on the List which, at the time of entry into force of the decree:

- leased on the basis of consent to the investment plan given by the competent commission in accordance with the regulations governing the priority right to lease agricultural land;

- leased on the basis of ownership of infrastructure facilities;

- leased for more than ten years.

By the way, in the restitution procedure, most problems were and still are about the return of agricultural land. There was much more state-owned land in all local selfgovernment units in the whole of Serbia than land claimed in the restitution procedure. The Administration has compiled a list of cadastral parcels intended for return in the restitution procedure. But large areas of quality agricultural land are exempt from restitution. A number of restitution holders were given back quality land in one piece, and a large number of the remaining ones were offered encumbered land or fields belonging to low-quality land, small plots of land below or around one hectare, which are not next to each other, which no one wants, due to which led to a delay in the procedure of returning agricultural land (Agronews, 2020) and initiating numerous court proceedings.

Due to the insufficient allocation of the fund for the return of the land, the holders of restitution were put in an unequal position. Those who are offered inadequate land believe that they have been damaged, that the right to fair restitution and the principle of equality have been violated, and have opted for court proceedings because the state cannot return quality to some and bad to others, and there is a sufficient fund of state land that may be subject to restitution. 
In terms of determining the possibility of returning agricultural land in the restitution procedure, the authors analyzed the state of the existing state fund of state land in relation to the amount claimed in the restitution procedure in municipality Ruma in Vojvodina. In 2016, according to public data published on the website of the Administration, there were a total of 7,207,4594 hectares of arable agricultural land in the observed local self-government. Based on the Agency's public data, restitution holders are claiming $1,248,1484$ hectares, representing only $17.32 \%$ of the total available state fund. In all neighboring municipalities, the percentage of claims for restitution titular was approximate, so that in Ruma, there is enough quality state land to return in the restitution procedure.

Notwithstanding the above, some of the restitution holders received quality agricultural land and others, with the threat of rejection of the request for land return by the Agency, were forced to take low-quality land, in several small plots, separated from each other, or to have long disputes with state. This obviously discriminated against a large number of restitution holders. In addition to the above, the proceedings are taking too long, which violated the right of the restitution holder to resolve their claims within a reasonable time, which is guaranteed by the Constitution of the Republic of Serbia.

The authors investigated the case of seventeen heirs who claimed agricultural land from 4 of their ancestors, who were deprived of quality agricultural land in a cadastral municipality in JLS Ruma. Since there was no land to be returned in that cadastral municipality (except for 4 ha of class IV pastures, which no one wanted to take until then due to poor position and quality), the heirs were offered about 300 plots, mostly small or slightly above one hectare, low-quality lands from III to VI class. The surveyor, whom the Agency chose to do the expertise, said that the best piece of land of all that was the one when "no one wanted".

Since the restitution procedure lasted too long (seven years) outside all rational legal deadlines, and the heirs were offered several small low-quality plots or rejection of the request for returning land (which would be illegal but would put the heirs in a situation to conduct years-long proceedings), the heirs opted for a less bad combination: to take 24 small, distant plots and to sue for damages.

At the basis of such confrontations between the state and the titulars of restitution obviously lies the lack of will of the state to return quality agricultural land, when there is enough for all the titulars of restitution.

\section{Conclusion}

The restitution of property confiscated from previous owners in the post-World War II period in the countries of the communist system, Eastern and Central Europe, had two goals: it was part of the overall reforms of those countries that abandoned the communist social order and redress the injustices done to previous owners. Economically stronger countries and those with a regulated legal system have implemented restitution in a shorter time, with fair economic compensation, while in other countries, this process has 
taken too long, with the dissatisfaction of restitution holders. In doing so, all countries have envisaged similar models for the return of confiscated property, including return in nature (return of confiscated property or return of other property of the same type) and / or financial form (monetary compensation, bond issuance or acquisition of stateowned shares).

In Serbia, the Law on Restitution of Confiscated Property and Compensation prescribes two basic principles in restitution proceedings: the principle of priority of restitution of property in nature in all cases where that property exists and may be subject to restitution and the principle of protection of the acquirer. The taken away will be returned to the ownership and state to the former owner or his legal successor, and only if the return of the property is not possible, the former owner or his legal successor is entitled to compensation.

Also, the restitution process in Serbia began more than two decades after the privatization process began. This unjustified discrepancy greatly influenced the legal solutions, and then their implementation in practice. The analysis of regulations, and then the practice that took place on the basis of those regulations, indicates obvious contradictions, inconsistencies and legal gaps in the normative part, which inevitably contributed to the different position of subjects in the restitution procedure, which in many cases has noticeable elements of discrimination (Veselinov, 2017). Therefore, substantial changes in legislation should be made and the injustice done to numerous restitution holders should be corrected, which would also suspend numerous proceedings before the courts.

For the implementation of restitution in Serbia, it is not enough just to pass a law on property restitution and compensation. It has been shown that it is necessary to take a number of essential measures to achieve the necessary political and social consensus in order to fairly return confiscated property, especially when returning agricultural land, in the form of substitution, determination and allocation of agricultural land for restitution, precise definition of obligations of state bodies and achieving synergy of the state apparatus in the field of restitution, which, when it comes to returning agricultural land, has not shown satisfactory results.

Neglect, adoption of unfortunate solutions, or delayed implementation of adequate measures leave large groups of the populations (particularly peasants) alienated, and enhance further political polarization of the post - communist societies.

\section{Acknowledgements}

Paper is a part of a research within the project financed by the Ministry of Education, Science and Technological Development of the Republic of Serbia.

\section{Conflict of interests}

The authors declare no conflict of interest. 


\section{References}

1. Agronews, The state exempted the best land from restitution, Belgrade, Serbia, Retrieved from: http://www.agronews.rs/država-iz-restitucije-izuzela-najboljezemljište/, (April 21, 2020)

2. Ceppei Guidelines from 2009, Retrieved from: http://ceppei.ba/bos/index. php?option=com/, (April 21, 2020)

3. Decision of the Constitutional court of Serbia No. IUz-429/2011 dated on April, $18^{\text {th }}, 2013$.

4. Decree of criteria for determining the area of agricultural and forest land in the procedure of returning confiscated property (“Official Gazette of RS”, No. 29/2018).

5. Decision od the Constitutional Court of Serbia No. I-Uz.119 / 2008 dated on April $20^{\text {th }}, 2011$ - "Official Gazette of RS", No. 44/2011).

6. Decision of the Constitutional Court of Serbia No. IUz-462/2011 dated on April $11^{\text {th }}, 2013$.

7. European Convention for he Protection of Human Rights and Fundamental Freedoms, Italy, (1950), https:/ www.echr.coe.int/documents/convention_eng.pdf

8. Gower, L. (1992): Konzminski, K., A. (1997), Restitution of Private Property: Reprivatization in Central and Eaastern Europe, Communist and Post - Communist studies, The Regents of University of California, Press, Published by Elsevier Science Ltd, Great Britain, p. 95-106, (Retrieved from: https://online.ucpress.edu/ cpcs/article/30/1/95/399/Restitution-of-Private-Property-Re-privatization) https:// doi.org/10.1016/S0967-067X(96)00025-6

9. Gulan, B., (2015). The Fate of Confiscated Property 2915. Banat Cultural Centre, Novo Mileševo, p. 232-240.

10. HERETICUS, (2020), Retrieved from: http://www.hereticus.org/arhiva2004-4/ denacionalizacija-u-srbiji-de-lege-ferenda.html\#more-166, (April 21, 2020)

11. Institute of Law and Finance, LLC, Belgrade, Serbia, Restitution in Serbia and post-comunist countries, Retrieved from: http://ipf.rs/restitucija-u-srbiji-iposkomunističkim-zemljama/ (April 21, 2020)

12. Jugović, A., (2009) Restitution as a value turning point in the democratization of Serbian society, Rehabilitation and restitution in Serbia - Proceedings of the round table Belgrade, Center for the Advancement of Legal Studies, Congress of Serbian Unification, Studenica Endowment, p. 289-297.

13. Judgement of the European Court of Human Rights in the case of Jantner v. Slovakia, no. 39050/97, paragraph 34, March 4 ${ }^{\text {th }}$, 2003., https:// hudoc.echr.coe. int/app/conversion/pdf/?library=ECHR\&id=001-60964\&filename $=001-60964 . p d f$

14. Law of restitution of Taken Away property and Compensation ("Official Gazette of RS", No. 72/2011, 108/2013, 142/2014, 88/2015 Serbia - decision of the Constitutional Court i 95/2018). 
15. Projuris, Belgrade, Restitution and compensation for property confiscated without compensation after 1945 - regulations, experiences and case study in Serbia and region, Retrieved from: http://projuris.org/denacionalizacija.html (June 6, 2020)

16. Samardžić, S., (2012), Natural restitution in Serbia - period of gestation, Proceedings of the Faculty of Law in Novi Sad, No.4, p. 449 - 461. https://doi. org/10.5937/zrpfns46-3340

17. Surdykowska, S., T., (1996) Priwatyzacja (Privatisation), PWN, Washav, p. 119. (Retrieved from: https://watermark.silverchair.com/cpcs_30_1_95.pdf?token=AQ ECAHi208BE49Ooan9kkhW_Ercy7, (March 15, 2020).

18. Sutela, P. (1998) Privatisation of the Countries of Eastern and Centarl Europe and the Soviet Union, The United Nations University, WIDER Working Paper 146/1998, p. 16-20.

19. Veselinov, J., (2017): Legal status of former owners in restitution procedure in Serbia, Faculty of Economics and Justice, University of Economics, p. 1-12.

20. WJRO, Israel, Restutition by Country, North Macedonia Operations, Retrieved from: https://wjro.org.il/our-work/restitution-by-country/, (April 21, 2020). 